\title{
Impact of armed conflict on the seasonal migratory practices of Gujjar and Bakkarwal tribes in Jammu and Kashmir
}

\author{
Kavita Suri \\ Associate Professor, Department of Lifelong Learning, (Formerly, Centre for Adult, Continuing Education \& \\ Extension), University of Jammu, Jammu and Kashmir
}

\begin{abstract}
The Gujjars and Bakkarwal scheduled tribes form the third largest community in Jammu and Kashmir, one of the border states of India and constitute 8.1 percent of the total population in the state. Primarily nomadic communities who move to the lower, middle and higher mountain reaches in the Pir Panjal mountain ranges and even beyond up to Kashmir and Ladakh with the change in seasons along with their flock of buffalos, goats and sheep, they have been severely hit by the armed conflict in Jammu and Kashmir. The present paper aims to understand the impact of conflict situations in Jammu and Kashmir on the migratory practices of Gujjars and Bakkarwals. It also seeks to analyze the annual pattern of migration from upper journeys to the higher hills and return journeys to the lower hills and plains.
\end{abstract}

Keywords: Tribes, Kashmir, conflict, Gujjars, Bakkarwals, seasonal migration, pastures

\section{Introduction}

Jammu and Kashmir, a border state of India is inhabited by a number of tribal communities who have settled down in all parts of this Himalayan state. For many years, Jammu and Kashmir had no Scheduled Tribe (ST) population. It was only in 1989 that eight communities vide the Constitution (Jammu \& Kashmir) Scheduled Tribes Order, 1989 and four communities, namely Gujjar, Bakkarwal, Gaddi and Sippi were notified as the Scheduled Tribes vide the Constitution (Scheduled Tribes) Order (Amendment) Act, 1991. These twelve hill tribes of Jammu and Kashmir which were granted ST status are Balti, Beda, Bot (Boto), Brokpa (Drokpa, Dard, Shin), Changpa, Garra, Mon, Purigpa, Gujjar, Bakkarwal, Gaddi and Sippis. All the twelve Scheduled Tribes (STs) were enumerated officially for the first time during the 2001 census recording a population of $1,105,979$.

The Scheduled Tribes account for 11.9 per cent of the total population of the State as per Census 2011. The total population of the state, as per Census 2011, is 1,25,41302 including male population of 66,40662 and female population of 59,00640. The Census 2011 shows the entire ST population of the state at 14, 93, 299 in comparison to 11,0,5979 of Census 2001. Thus, there is an increase of 3,87,320 in schedule tribe population of the state. As the Census 2011 figures on the individual population of 12 ST communities of J\&K are not yet available, however as per Census 2001, Gujjar is the most populous tribe having a population of 763,806, thus forming 69.1 percent of the total ST population. Bot is the second major tribe having a population of 96,698 , followed by Bakkarwal $(60,724)$ and Brogpa $(51,957)$. Gujjar along with the three tribes constitute 88 per cent of the total tribal population (Census 2001) whereas Balti, Purigpa and Gaddi having population ranging from 38,188 down to 35,765 form 10.2 per cent of the total ST population. Remaining five tribes, Sippi, Changpa, Mon, Garra and Beda along with generic tribes constitute the residual proportion (1.9 per cent). Among all the tribes, Beda is the smallest group with a population of 128 .

Table 1: Population of Schedules Tribes in J\&K

\begin{tabular}{|l|l|l|l|}
\hline NAME & $\begin{array}{l}\text { POPULATION OF ST Census } \\
\mathbf{2 0 1 1}\end{array}$ & $\begin{array}{l}\text { POPULATION OF } \\
\text { Census 2001 }\end{array}$ & STARIATION \\
\hline JAMMU \& KASHMIR & $14,93,299$ & $11,0,5979$ & $3,87,320$ \\
\hline Kupwara & 70352 & 51753 & 18599 \\
\hline Badgam & 23912 & 14547 & 9365 \\
\hline Leh & 95,857 & 96,174 & -317 \\
\hline Kargil & $1,22,336$ & $1,05,377$ & 16959 \\
\hline Poonch & $1,76,101$ & $1,49,018$ & 27083 \\
\hline Rajouri & $2,32,815$ & $1,60,049$ & 72766 \\
\hline Kathua & 53307 & 33969 & 19338 \\
\hline Baramula & 37705 & 28886 & 8819 \\
\hline Bandipore & 75374 & 54996 & 20378 \\
\hline Srinagar & 8935 & 3485 & 5450 \\
\hline Ganderbal & 61070 & 41959 & 19111 \\
\hline Pulwama & 22607 & 10552 & 12055 \\
\hline
\end{tabular}


Impact of armed conflict on the seasonal migratory practices of Gujjar and Bakkarwal tribes in

\begin{tabular}{|l|l|l|l|}
\hline Shopian & 21820 & 10944 & 10876 \\
\hline Anantnag & $1,16,006$ & 80,856 & 35150 \\
\hline Kulgam & 26525 & 20287 & 6238 \\
\hline Doda & 39216 & 28400 & 10816 \\
\hline Ramban & 39772 & 29353 & 10419 \\
\hline Kishtwar & 38149 & 27917 & 10232 \\
\hline Udhampur & 56309 & 42875 & 13434 \\
\hline Reasi & 88365 & 60753 & 27612 \\
\hline Jammu & 69193 & 42089 & 27104 \\
\hline Samba & 17573 & 11740 & 5833 \\
\hline
\end{tabular}

Source: Census 2011

The Gujjars and Bakkarwal tribes, together with their unique social, cultural and linguistic identities form the third largest community in Jammu and Kashmir and constitute 8.1 percent of the total population in the state, according to the Census of India 2001. In India, Gujjar Bakkarwals are spread throughout the northern part of the Himalayan Range. This includes the states of Uttarakhand, Himachal Pradesh and Punjab. In Pakistan, Bakkarwals are found in the hilly northern parts of Punjab as well as parts of the North West Frontier Province. In Jammu and Kashmir in India, they are found in all the three regions of the state including Jammu (comprising districts of Jammu, Kathua, Udhampur, Poonch, Rajouri Districts), the Kashmir Valley (comprising the districts of Srinagar, Baramulla, Kupwara, Pulwama, Budgam and Anantnag) and Ladakh (comprising Kargil). The Gujjar tribe has the highest concentration in Poonch and Rajouri districts in Jammu province followed by Anantnag, Udhampur and Doda districts. The state of Jammu and Kashmir has a Bakkarwal population of about 60,724 in 2001 (Jammu Kashmir Digest of Statistics 2011).

Table 2: Percentage of Scheduled Tribe to total population in Jammu and Kashmir

\begin{tabular}{|c|c|c|}
\hline $\begin{array}{l}\text { DISTRICT } \\
\text { CODE }\end{array}$ & DISTRICT & Percentage Of STs ( 2011) \\
\hline & JAMMU \& KASHMIR & 11.9 \\
\hline 1. & Kargil & 86.9 \\
\hline 2. & Leh(Ladakh) & 71.8 \\
\hline 3. & Punch & 36.9 \\
\hline 4. & Rajouri & 36.2 \\
\hline 5. & Reasi & 28.1 \\
\hline 6. & Ganderbal & 20.5 \\
\hline 7. & Bandipore & 19.2 \\
\hline 8. & Kishtwar & 16.5 \\
\hline 9. & Ramban & 14 \\
\hline 10. & Anantnag & 10.8 \\
\hline 11. & Udhampur & 10.1 \\
\hline 12. & Doda & 9.6 \\
\hline 13. & Kathua & 8.6 \\
\hline 14. & Shupiyan & 8.2 \\
\hline 15. & Kupwara & 8.1 \\
\hline 16. & Kulgam & 6.2 \\
\hline 17. & Samba & 5.5 \\
\hline 18. & Jammu & 4.5 \\
\hline 19. & Pulwama & 4 \\
\hline 20. & Baramula & 3.7 \\
\hline 21. & Badgam & 3.2 \\
\hline 22. & Srinagar & 0.7 \\
\hline
\end{tabular}

\section{Source: Census 2011}

Gujjars who were primarily a nomadic community, have now settled down to a larger extent in permanent villages in the plains bordering the foot hills and have taken to cultivation of land as their primary occupation. But there are many semi-settled or sedentary transhumant Gujjars who combine the cultivation of land with pastoralism. They move to the lower and middle mountain areas in Pir Panjal pastures in the summer with their flock of buffalos where they engage in cultivation and come back to the plains in the winters. The Bakkarwals who are the goat (Bakri) breeders are also primarily pastoral nomads rearing goat and sheep for livelihood. They also leave their homes each summer for the high-altitudes of Himalayas and spend their winter in plains and foot hills of Shivaliks. During their journeys to the higher reaches of the mountains during summers when the snows melt and the passes open, the Bakkarwals trek to the higher pastures of the Pir Panjal ranges where they graze their herd of sheep. Bakkarwals take long hard journeys to the higher mountains as long as even up to $500 \mathrm{kms}$. It may take them as many as sixty days to reach these meadows. The nomadic Bakkarwals from Ranbir Singh Pura area in the plains of Indo-Pak International Border, Akhnoor, lower hills of Rajouri and Kalakote travel 
over $500 \mathrm{kms}$ of journey with their caravans to Drass, Suru valley and Kargil in Ladakh via Kashmir valley and Pir Panjal ranges.

\section{Seasonal migration patterns among nomadic Gujjar Bakkarwals of Jammu and Kashmir}

With the onset of summers each year, the Gujjars and Bakkarwals migrate along with their livestock to upper reaches of Himalayas through seven major tribal migration routes. Besides, seven major migratory routes, there are many sub-routes also. All the major routes and sub-routes pass through various mountain passes which are known as Gallis in the local language. Various Dheras (clans comprising of various households) of nomads start their journey from various places like Marhot, Mendhar, Rajouri, Poonch, Surankote, Thanamandi etc. Every year around 20,000 people migrate to summer pastures and return back after the grazing season is over. Migration in the Jammu usually takes place from three regions: Poonch, Rajouri and Kishtwar regions. The Poonch and Rajouri migration makes for the heaviest route out of the three. All these routes lead to different passes or Gallis in the Pir Panjal ranges.

Since the eruption of militancy in Jammu and Kashmir, the security forces including the police and army has been keeping an eye on the migratory population and checking the movement of militants along with them. For this purpose, the security agencies and the state administration has set up Joint Forest Check Posts (JCP) since 2009 to monitor and record the movement of Gujjar-Bakkarwals. Under this initiative, each JCP maintains a joint biometric observation or monitoring of the migration by one representative each from the police, army, a veterinary doctor from the Animal Husbandry Department and a Forest Department official. There are currently six such check posts in the Poonch-Rajouri located at Mandi, Kulali, Behramgala, Thanamandi, Darhal and Mahrot, along the routes followed by the Bakkarwals. Another JCP was set up at Kandi in the initial years.

Table 3: Migration pattern of the Deras (nomadic families) in Poonch-Rajouri in 2012

\begin{tabular}{|c|c|c|c|c|c|}
\hline S. No. & $\begin{array}{l}\text { Joint Check Post } \\
\text { (JCP) }\end{array}$ & Originated from & Middle reaches & Higher reaches & Destination \\
\hline 1. & Behramgala & $\begin{array}{l}\text { Bachianwali } \\
\text { Bhattardurian } \\
\text { Darabad } \\
\text { Fasalabad } \\
\text { Sunderbai } \\
\text { Kalakote } \\
\text { Mendhar } \\
\text { Naushera }\end{array}$ & $\begin{array}{l}\text { Dhokri } \\
\text { Malhan } \\
\text { Mari } \\
\text { Khotewali } \\
\text { Karu } \\
\text { Said Baker } \\
\text { Suinay } \\
\text { Nad Doba } \\
\text { Naka majari } \\
\text { Khor marha }\end{array}$ & $\begin{array}{l}\text { Jaranwali } \\
\text { Tatakuti } \\
\text { Khutwali } \\
\text { Kutpathri } \\
\text { Chatapani } \\
\text { Poshian } \\
\text { Patankote }\end{array}$ & $\begin{array}{l}\text { Bagnuwali } \\
\text { Dogrian } \\
\text { Srinagar } \\
\text { Sonamarg } \\
\text { Shopian } \\
\text { Meena Marg } \\
\text { Psohiana } \\
\text { Nakka Majdhari }\end{array}$ \\
\hline 2. & Kulali & $\begin{array}{l}\text { Dandidhar } \\
\text { Fasalabad } \\
\text { Kallar katal } \\
\text { Marrah } \\
\text { Gunthal } \\
\text { Marhot } \\
\text { Mohra Bachai }\end{array}$ & $\begin{array}{l}\text { Dongiwali } \\
\text { Said baker } \\
\text { Galinar } \\
\text { Muri } \\
\text { Hingli } \\
\text { Dhara } \\
\text { Sangla } \\
\text { Kalar } \\
\text { Suranthal } \\
\end{array}$ & $\begin{array}{l}\text { Gajnawa } \\
\text { Jaranwali } \\
\text { Lugni } \\
\text { Bearwali } \\
\text { Dobigaj }\end{array}$ & $\begin{array}{l}\text { Hill Kaka } \\
\text { Upper Tarkanna } \\
\text { Dhanawali } \\
\text { Jotiyawali } \\
\text { Tungwali } \\
\text { Ranjati }\end{array}$ \\
\hline 3. & Marhote & $\begin{array}{l}\text { Naushera } \\
\text { Rajouri } \\
\text { Sunderbani } \\
\text { Kalakote }\end{array}$ & $\begin{array}{l}\text { Galinar } \\
\text { Muri } \\
\text { Hingli } \\
\text { Dhara } \\
\text { Sangla } \\
\text { Suranthal }\end{array}$ & $\begin{array}{l}\text { Gajnawa } \\
\text { Jarawali } \\
\text { Lugni } \\
\text { Bearwali } \\
\text { Dobigaj }\end{array}$ & $\begin{array}{l}\text { Baramulla } \\
\text { Kupwara } \\
\text { Bandipura } \\
\text { Gulmarg }\end{array}$ \\
\hline 4. & Mandi & $\begin{array}{l}\text { Rajada } \\
\text { Double Kot } \\
\text { Single Kot } \\
\text { Soodh Moh } \\
\text { Solian } \\
\text { Hari Dodi } \\
\text { Mohra Bachai }\end{array}$ & $\begin{array}{l}\text { Gursai } \\
\text { Batawali } \\
\text { Khangar } \\
\text { Bari bahak } \\
\text { Ban } \\
\text { Gari Bahak } \\
\text { Gangial } \\
\text { Dodi } \\
\text { Suranthal }\end{array}$ & $\begin{array}{l}\text { Dhara } \\
\text { Dorwali } \\
\text { Daranwa Pass } \\
\text { Patri } \\
\text { Khutwali }\end{array}$ & $\begin{array}{l}\text { Derawali } \\
\text { Ban Jabada } \\
\text { Bari Behak } \\
\text { Battanwali } \\
\text { Channuwali } \\
\text { Kolion } \\
\text { Sangao } \\
\text { Kuliwali } \\
\text { Paanch Katta } \\
\text { Sodhan } \\
\text { Sangad } \\
\text { Chottanad } \\
\end{array}$ \\
\hline 5. & Darhal & $\begin{array}{l}\text { Tanda (Jammu) } \\
\text { Akhnoor } \\
\text { Villages of Rajouri } \\
\text { district }\end{array}$ & $\begin{array}{l}\text { Kandi Pairi } \\
\text { Galian } \\
\text { Jatwala } \\
\text { Pajja } \\
\text { Bhediwala }\end{array}$ & $\begin{array}{l}\text { Kharimarg } \\
\text { Kulian } \\
\text { Shakarmarg } \\
\text { Danna } \\
\text { Jalamang } \\
\end{array}$ & $\begin{array}{l}\text { Bela } \\
\text { Sarhota } \\
\text { Dhudwali } \\
\text { Chhambarwali } \\
\text { Rupri Galli } \\
\end{array}$ \\
\hline
\end{tabular}


Impact of armed conflict on the seasonal migratory practices of Gujjar and Bakkarwal tribes in

\begin{tabular}{|c|c|c|c|c|c|}
\hline & & & $\begin{array}{l}\text { Lami Behek } \\
\text { Margari } \\
\text { Panj Kathha } \\
\text { Khud } \\
\text { Sawaya }\end{array}$ & Jhanjhwali & $\begin{array}{l}\text { Sonamarg } \\
\text { Gulmarg } \\
\text { Shopian } \\
\text { Srinagar } \\
\text { Pir Panjal } \\
\end{array}$ \\
\hline 6. & Thanamandi & $\begin{array}{l}\text { Villages of Rajouri } \\
\text { district }\end{array}$ & $\begin{array}{l}\text { Manial } \\
\text { Azmtabad } \\
\text { Bara Chhar } \\
\text { Kopra } \\
\text { Nerian }\end{array}$ & $\begin{array}{l}\text { DKG } \\
\text { Dorewali } \\
\text { Nai Hatti } \\
\text { Ratan Pir Galli } \\
\text { Sigari } \\
\text { Birnala }\end{array}$ & $\begin{array}{l}\text { Shopian } \\
\text { Budgam } \\
\text { Kargil } \\
\text { Ganderbal } \\
\text { Bandipura } \\
\text { Pahalgam } \\
\text { Sonamarg } \\
\text { Srinagar } \\
\text { Baramulla } \\
\text { Gurez } \\
\text { Pulwama }\end{array}$ \\
\hline 7. & Kandi & $\begin{array}{l}\text { Villages of Rajouri } \\
\text { district }\end{array}$ & $\begin{array}{l}\text { Lowa Pathri } \\
\text { Phulwai } \\
\text { Mandarniwala } \\
\text { Nakka } \\
\text { Kattha }\end{array}$ & $\begin{array}{l}\text { Marguri } \\
\text { Panch } \\
\text { Gabbar } \\
\text { Chee Sari } \\
\text { Rupri Galli }\end{array}$ & $\begin{array}{l}\text { Kauri Hill } \\
\text { Kesri Hill } \\
\text { Rupri Galli } \\
\text { Shopian } \\
\text { Srinagar } \\
\text { Pir Panjal } \\
\text { Gulmarg } \\
\text { Sonamarg }\end{array}$ \\
\hline
\end{tabular}

Source: Joint Forest Check Posts (JCP) Records 2012

Traditionally, the seasonal migration commences in the first week of April each year and generally the upward movement is completed in the last week of June or the first week of July.

The first to move are Bakkarwals whose livestock are hard and can survive on the short grass and shrubs that sprout after winter. The movement is to make maximum use of nature's bounty in the form of good grazing for their flocks. The routes followed are centuries old and particular families follow particular routes without deviation. The dhoks(mud \& stone houses) and grazing grounds enroute their final destination may not belong to that family who merely use the intermediary dhoks as staging areas. The locations where the Deras halt enroute and their duration of stay both during migration and reverse migration often differs. However Deras have certain earmarked Dhoks which are used by them every year. The carvans generally move along the roads for convenience and to avoid traffic. The movement is in the early morning and the routes of migration and reverse migration differ for some deras and there is no set pattern to this variation.

The nomadic Deras originating from Rajouri and Naushera, depending upon their preferred destination or the location of their dhoks (temporary shelters) either take the Bhimber Gali-Jaran Wali Gali road and onward through the JCPs or through the JCPs of Thanamandi, Darhal and Kandi. The carvans crossing Thanamandi joint check post originate from Akhnoor and go to Bhamala-Sunderbani-Narian-Chingus-Rajouri-SaajThanamandi-Manhal-Azmatabad-Naili-DKG-Ratan Pir pass and Banjh. Another route of Deras is from Akhnoor-Bhamla-Sunderbani-Narian-chingas-Rajouri-Gurian-Darhal-Pargal-Harimarg-Shakarmarg-Jalamang and then Naushera-Narian-Rajouri-Gurian-Pargal-Kharimarg- Shakarmarg/Jalmang. Both the routes taken by the Deras cross through JCP Darhal.

The carvans crossing Kandi JCP have their start point at Sundarbani-Dharamasal-kalakote-Tatta PaniKhu- Marhota-Kanthol-Kandi and beyond till Bahgsar Galli/Rupri Gali. Another route for the same JCP is Sunderbani-Narian-Sial Sui- Samrot-Khu-Marhota-Kandi-Marguri-Panch Gabbar-Bhagsar Gali-Rupri Galli. The deras also take the from Sundarbani-Maho Gala-Kanthol-Kandi-Daraj-Mandu gala-Banj-Bhagsar GalliRupri Galli-Gurwatan.

\section{Conflict situations in Jammu and Kashmir and Gujjar Bakkarwals}

Jammu and Kashmir was hit by an armed conflict in 1989. Broadly termed as 'proxy war' being waged from across the border by Pakistan with an objective to have control over Kashmir valley, the initial armed struggle started with the objective to carve an independent Kashmir from rest of Jammu and Kashmir whose key players were outfits like Jammu and Kashmir Liberation Front (JKLF), Hizbul Mujahideen etc. The Gujjar Bakkarwal population of Jammu and Kashmir has been badly hit by the armed conflict which erupted in the border state in 1989. Since the beginning of the armed insurgency in the border state, these two tribes were unwittingly drawn into this conflict.

\section{Objectives of the study}

1. To study the impact of armed conflict on the migratory practices of Gujjars and Bakkarwals.

2. To analyze the annual pattern of migration from upper journeys to the higher hills and return journeys to the lower hills and plains. 
3. To suggest some measures for the betterment of Gujjar Bakkarwals including their migratory practices.

\section{Methodology}

The present study is based on stratified random sampling which was done in Poonch and Rajouri. The areas chosen for the study of the migratory practices of nomads were Poonch and Rajouri as most of the seasonal migration takes place through the Pir Panjal ranges in these two districts only. A number of interviews were conducted besides the case studies and questionnaire was used. Besides the primary data, secondary sources were collected from the books, journals, seminar papers, websites, newspapers etc.

\section{Limitations of the study}

The study could have been conducted in the entire Pir Panjal ranges. But due to time and resources restraint, it was not extended to other parts.

\section{Results and Discussions}

The protracted conflict in Jammu and Kashmir has impacted the lives of the Gujjars Bakkarwals. The worsening of the security situation in J\&K did not stop the two great annual seasonal migrations but it did expose them to new pressures. As the terrorists would remain hidden in the dense forests in the upper reaches of the mountains especially in Pir Panjal ranges, the nomads who would also go to the higher reaches, were seen as a keen element in the escalated violence in Jammu and Kashmir. Travelling to far flung regions they would often come into contact with the militants who also used these areas to hide from the security forces. The security forces would also see their journeys to the higher regions as a source of support to the various terrorist outfits operating in the higher ridges. The nomads were sandwiched between the militants and the security forces and were hit from either side. If they won't listen to the ultras, they were bound to be hit by militants' bullet and if they were caught helping the militants, then the army would not leave them. Not only the nomads meant food, shelter, directions across the remote areas, carrying their ammunition and equipments for the militants but also a plethora of other support like sneaking past the security forces with the nomads posing off as part of their caravans while hiding their arms and ammunition in their belongings atop the horses that the Bakkarwals possessed. This exposed the tribal population to further vulnerability and more retaliation of the hands of the militant cadres resulting which many of them abandoned their age-old practice of pastoralism and stopped moving as part of their annual migration for fear of gun.

Table 4a) Summer Migration of Gujjar Bakkarwals from 17 April - 4 August 2012

\begin{tabular}{|c|c|c|c|c|c|c|}
\hline $\begin{array}{l}\text { Joint Check } \\
\text { Post (JCP) }\end{array}$ & $\begin{array}{l}\begin{array}{l}\text { Total number } \\
\text { of Deras } \\
\text { (families) } \\
\text { movement }\end{array} \\
\end{array}$ & $\begin{array}{l}\text { Number } \\
\text { of Males }\end{array}$ & $\begin{array}{l}\text { Number } \\
\text { of females }\end{array}$ & $\begin{array}{l}\text { Number } \\
\text { of Children }\end{array}$ & Total persons & $\begin{array}{l}\text { Total } \\
\text { animals }\end{array}$ \\
\hline Behramgala & 583 & 1436 & 865 & 946 & 3247 & 47012 \\
\hline Kulali & 118 & 207 & 176 & 286 & 669 & 5704 \\
\hline Marhot & 1702 & 2474 & 2533 & 2933 & 7940 & 29927 \\
\hline Mandi & 1538 & 1538 & 978 & 996 & 3509 & 78232 \\
\hline Darhal & 496 & 978 & 297 & 73 & 1348 & 19491 \\
\hline Thanamandi & 1383 & 2909 & 1387 & 859 & 5155 & 65704 \\
\hline Grand total & 5820 & 9542 & 6236 & 6093 & 21886 & 246070 \\
\hline
\end{tabular}

Source: Joint Check Posts (JCPs) Records 2012

Table 4b): Winter (reverse) migration of Gujjar Bakkarwals from 13 September - 15 November 2012

\begin{tabular}{|c|c|c|c|c|c|c|}
\hline $\begin{array}{l}\text { Joint Check Post } \\
\text { (JCP) }\end{array}$ & $\begin{array}{l}\text { Total number } \\
\text { Of Deras } \\
\text { (families) } \\
\text { movement }\end{array}$ & $\begin{array}{l}\text { Number } \\
\text { of Males }\end{array}$ & $\begin{array}{l}\text { Number } \\
\text { of females }\end{array}$ & $\begin{array}{l}\text { Number } \\
\text { of Children }\end{array}$ & Total persons & $\begin{array}{l}\text { Total } \\
\text { animals }\end{array}$ \\
\hline Kulali & 20 & 35 & 24 & 39 & 98 & 1609 \\
\hline Marhot & 837 & 971 & 1021 & 1326 & 3318 & 11732 \\
\hline Mandi & 302 & 484 & 303 & 450 & 1237 & 29623 \\
\hline Thanamandi & 786 & 1858 & 718 & 560 & 3136 & 60306 \\
\hline Grand total & 2194 & 3774 & 2317 & 2577 & 8668 & 127298 \\
\hline
\end{tabular}

Source: Joint Check Posts (JCPs) Records 2012

The analysis of the data and the interviews conducted with the nomadic members of Gujjar Bakkarwal tribes shows that the conflict has impacted the livelihood of nomadic shepherd community as the presence of militants in the upper reaches and their atrocities and fear of retaliation or safety of their family members, made most of 
the families abandon their annual migratory practices. Many of them were forced to remain in lower areas only and abandon the migration making their livelihood into an unviable proposition.

Table 5a) Summer Migration of Gujjar Bakkarwals from 05 April 2011 - 20 July 2011

\begin{tabular}{|c|c|c|c|c|c|c|}
\hline $\begin{array}{l}\text { Joint Check Post } \\
\text { (JCP) }\end{array}$ & $\begin{array}{l}\text { Total number } \\
\text { of Deras } \\
\text { (families) } \\
\text { movement }\end{array}$ & $\begin{array}{l}\text { Number } \\
\text { of Males }\end{array}$ & $\begin{array}{l}\text { Number } \\
\text { of females }\end{array}$ & $\begin{array}{l}\text { Number } \\
\text { of Children }\end{array}$ & Total persons & $\begin{array}{l}\text { Total } \\
\text { animals }\end{array}$ \\
\hline Behramgala & 652 & 1204 & 832 & 328 & 2364 & 37556 \\
\hline Kulali & 123 & 325 & 295 & 167 & 787 & 4804 \\
\hline Marhot & 1507 & 2182 & 2561 & 3191 & 7934 & 21957 \\
\hline Mandi & 1070 & 1644 & 844 & 1221 & 3709 & 76561 \\
\hline Darhal & 514 & 672 & 729 & 385 & 1786 & 22477 \\
\hline Thanamandi & 727 & 1542 & 680 & 486 & 2708 & 61450 \\
\hline Grand total & 4593 & 7569 & 5941 & 5778 & 19288 & 224805 \\
\hline
\end{tabular}

Source: Joint Check Posts (JCPs) Records 2011

Table 5b): Winter (reverse) migration of Gujjar Bakkarwals from 11 September - 19 November 2011

\begin{tabular}{|l|l|l|l|l|l|l|}
\hline $\begin{array}{l}\text { Joint Check Post } \\
(\text { JCP) }\end{array}$ & $\begin{array}{l}\text { Total number } \\
\text { Of Dumber } \\
\text { (families) } \\
\text { movement }\end{array}$ & $\begin{array}{l}\text { Number } \\
\text { of Males }\end{array}$ & $\begin{array}{l}\text { Number } \\
\text { of females }\end{array}$ & $\begin{array}{l}\text { Number } \\
\text { of Children }\end{array}$ & $\begin{array}{l}\text { Total persons } \\
\text { animals }\end{array}$ \\
\hline Behramgala & 163 & 278 & 202 & 114 & 594 & 6508 \\
\hline Kulali & 19 & 46 & 36 & 50 & 132 & 1076 \\
\hline Marhot & 210 & 314 & 367 & 395 & 2249 & 2651 \\
\hline Mandi & 547 & 867 & 484 & 898 & 52203 \\
\hline Darhal & 91 & 221 & 109 & 136 & 766 & 7091 \\
\hline Thanamandi & 587 & 1449 & 412 & 702 & 2563 \\
\hline Grand total & $\mathbf{1 6 1 7}$ & $\mathbf{3 1 7 5}$ & $\mathbf{1 6 1 0}$ & $\mathbf{2 2 9 5}$ & $\mathbf{7 0 8 0}$ \\
\hline
\end{tabular}

Source: Joint Check Posts (JCPs) Records 2011

According to a survey conducted in 2012 by Tribal Research and Cultural Foundation, a community based organization working on the Gujjar-Bakkarwals of Jammu and Kashmir; more than 39\% Gujjar-Bakkarwals who are migratory by tradition relinquished their nomadic lifestyle in these years of turmoil in the State. Heavy loss of precious lives and properties, lack of health and communication facilities and restriction on nomadic movement in upper reaches are few of the reasons, the survey said adding the main reason of declining in annual tribal movement is the killing of hundreds of nomadic Gujjar-Bakkarwals on upper reaches in the turmoil besides the restrictions imposed by the security agencies and militants on tribal migration in border and strategic areas.

The migratory practices of the nomads in Jammu and Kashmir have undoubtedly been impacted by the armed conflict. Firstly, ever since the militancy started in Jammu region, there has been a reduction in the number of Bakkarwals who would go up in the mountains some 30-40 years ago in comparison to the present times. After militancy erupted, the Bakarwals couldn't go up in their mountain pastures. When the militants would take their goats and other things, they could not help but stopped moving for fear of gun. Once militancy started, the militants started killing them, their dignity was destroyed, they lost their habitats and thus were hit badly. Few of the Bakarwals turned to farming which is very less seen among their tribes.

Secondly, the caravans have become smaller, the goats are no longer in plenty, the number of their cattle is reducing with each passing day and as they do not have any major land holdings, many of them have been forced to leave their centuries old tradition of nomadism and are forced to do labour work. They are no longer able to fend for themselves.

Thirdly, the Bakkarwals who travel to the higher reaches with their herd use forest land for resources. These forests proved shelter and food for many Bakarwals as many set camps under large trees. In the 1980's the Forest Department decided to close and fence off a major chunk of the forest land in the Jammu region. These forests and the Forest department wanted to conserve this land that fed the seasonal migrations of the nomads. There was huge dependence of these tribes on the forest area and its closure ultimately stopped many nomads from migrating. 
Impact of armed conflict on the seasonal migratory practices of Gujjar and Bakkarwal tribes in

Table 6: A comparative state of Deras movement of Gujjar Bakkarwals 2010-2012

\begin{tabular}{|l|l|l|l|l|l|l|l|l|l|}
\hline \multirow{2}{*}{$\begin{array}{l}\text { Joint Check } \\
\text { Post (JCP) }\end{array}$} & \multicolumn{3}{|c|}{ 2010 } & \multicolumn{3}{|c|}{ 2011 } & \multicolumn{3}{c|}{2012} \\
\cline { 2 - 11 } & Deras & Persons & Animals & Deras & Per & Animals & Deras & Per & Animal \\
\hline $\begin{array}{l}\text { Behram } \\
\text { Gala }\end{array}$ & 817 & 3652 & 49049 & 652 & 2364 & 37556 & 583 & 3247 & 47012 \\
\hline Kulali & 148 & 865 & 5391 & 123 & 787 & 4804 & 118 & 669 & 5704 \\
\hline Mandi & 945 & 3345 & 79959 & 1507 & 7934 & 21957 & 1538 & 3509 & 78232 \\
\hline Marhot & 1520 & 8437 & 26203 & 1070 & 3709 & 76561 & 1702 & 7940 & 29927 \\
\hline Darhal & 315 & 1164 & 15304 & 514 & 1786 & 22477 & 496 & 1348 & 19491 \\
\hline $\begin{array}{l}\text { Thana } \\
\text { mandi }\end{array}$ & 853 & 3246 & 71227 & 727 & 208 & 61450 & 1383 & 5155 & 65704 \\
\hline Total & $\mathbf{4 5 9 8}$ & $\mathbf{2 0 7 0 9}$ & $\mathbf{2 4 7 1 3 3}$ & $\mathbf{4 5 9 3}$ & $\mathbf{1 9 2 8 8}$ & $\mathbf{2 2 4 8 0 5}$ & $\mathbf{5 8 2 0}$ & $\mathbf{2 1 8 8 6}$ & $\mathbf{2 4 6 0 7 0}$ \\
\hline
\end{tabular}

Source: Joint Check Posts (JCPs) Records

The analysis of the data collected in the past three years also shows that there had been an increase in the total number of Deras that have migrated in 2012 as compared to previous two years. However there had been a sharp decline in the number of persons migrating (only 12095 compared to about 20,000 persons for lesser number of Deras). This sharp decline in the number of persons can also be attributed to the opening of Mughal Road and the new trend of people moving in transport to the grazing areas. Maximum number of Deras moved through the JCPs at Mandi, Marhot and Thanamandi areas whereas JCPs at Kulali, Darhal witnessed minimum migration. The analysis of the data also shows that the seasonal migrations commenced at least a week later than the usual time of the year in 2012. This can be attributed to the extended winters. The movement of nomads to the middle reaches was delayed as the areas were still covered with snow whereas from few JCPs, the movement was more as the availability of grass and cattle feed was more in their areas. In the upper reaches, the effect of summer is late.

The number of Deras which migrated from JCPs rose from 4593 in 2011 to 5779 in 2012 with corresponding increase in persons as well as sheep/goat/cattle and horses. Similarly, for reverse migration of Deras, the figures were 1617 in 2011 to 2260 in 2012.

In December 2011, 652 Deras moved from Behramgala JCP during their onward migration but only 163 deras returned. The number of Deras which migrated from the JCPs of Thanamandi and Darhal rose from 1132 in 2010 to 1240 in 2011 with corresponding increase in persons as well as sheep/goat/cattle and horses. However, the reverse migration of Deras from JCP Thanamandi and Darhal was significantly less in 2010 which was only 514 as compared to 678 in 2011.

Table 7a: Details of the migrating Deras for 2008-2010 obtained from the JCPs

\begin{tabular}{|c|c|c|c|c|c|}
\hline Year & JCP & Deras & Persons & Sheep/Goat & Cattle/Horses \\
\hline \multirow{8}{*}{2008} & Behramgala & 902 & 3298 & 32306 & 7167 \\
\hline & Kulali & 355 & 2044 & 10646 & 2386 \\
\hline & Marhot & 820 & 2062 & 4314 & 5928 \\
\hline & Mandi & 1028 & 4575 & 71020 & 9724 \\
\hline & Thanamandi & 943 & 3643 & 62415 & 9716 \\
\hline & Darhal & 667 & 1672 & 22350 & 2180 \\
\hline & Kandi & 526 & 2122 & 13222 & 1888 \\
\hline & Total & 5241 & 19416 & 216273 & 39989 \\
\hline \multirow{8}{*}{2009} & Behramgala & 326 & 1282 & 21685 & 1924 \\
\hline & Kulali & 221 & 1281 & 3528 & 1273 \\
\hline & Marhot & 766 & 4817 & 8722 & 6855 \\
\hline & Mandi & 1130 & 4694 & 72430 & 7945 \\
\hline & Thanamandi & 1017 & 3974 & 53754 & 6624 \\
\hline & Darhal & 456 & 1166 & 24828 & 2855 \\
\hline & Kandi & 447 & 1553 & 15421 & 994 \\
\hline & Total & 4363 & 18767 & 200368 & 28470 \\
\hline \multirow{8}{*}{2010} & Behramgala & 803 & 3655 & 43132 & 4949 \\
\hline & Kulali & 152 & 964 & 4882 & 686 \\
\hline & Marhot & 1520 & 8902 & 17146 & 8212 \\
\hline & Mandi & 964 & 3370 & 85862 & 4084 \\
\hline & Thanamandi & 853 & 3246 & 65113 & 6114 \\
\hline & Darhal & 315 & 1164 & 13865 & 1439 \\
\hline & Kandi & 209 & 805 & 7760 & 834 \\
\hline & Total & 4816 & 22106 & 237780 & 26318 \\
\hline
\end{tabular}


Impact of armed conflict on the seasonal migratory practices of Gujjar and Bakkarwal tribes in

Table 7b: Details of the reverse movement of migrating Deras for 2008-2010 obtained from the JCPs

\begin{tabular}{|c|c|c|c|c|c|}
\hline Year & JCP & Deras & Persons & Sheep/Goat & Cattle/Horses \\
\hline \multirow{8}{*}{2008} & Behramgala & 421 & 1947 & 15779 & 2461 \\
\hline & Kulali & 438 & 2582 & 12029 & 2696 \\
\hline & Marhot & 1161 & 6476 & 68947 & 7811 \\
\hline & Mandi & 653 & 2419 & 33345 & 3831 \\
\hline & Thanamandi & 876 & 3314 & 51267 & 5273 \\
\hline & Darhal & 244 & 573 & 10584 & 1043 \\
\hline & Kandi & 557 & 1578 & 6310 & 1573 \\
\hline & & 4350 & 18,889 & 198261 & 24688 \\
\hline \multirow{8}{*}{2009} & Behramgala & 366 & 2902 & 24346 & 4632 \\
\hline & Kulali & 231 & 1233 & 3410 & 1000 \\
\hline & Marhot & 412 & 1190 & 1963 & 1248 \\
\hline & Mandi & 685 & 2249 & 40337 & 3157 \\
\hline & Thanamandi & 898 & 3059 & 50655 & 6148 \\
\hline & Darhal & 205 & 518 & 7214 & 535 \\
\hline & Kandi & 192 & 849 & 3934 & 913 \\
\hline & Total & 2989 & 12000 & 131859 & 17633 \\
\hline \multirow{8}{*}{2010} & Behramgala & 280 & 1880 & 14461 & 1160 \\
\hline & Kulali & 13 & 77 & 90 & 64 \\
\hline & Marhot & 691 & 3834 & 7578 & 3582 \\
\hline & Mandi & 372 & 1742 & 34172 & 655 \\
\hline & Thanamandi & 881 & 3237 & 74767 & 4572 \\
\hline & Darhal & 213 & 763 & 8733 & 1313 \\
\hline & Kandi & 178 & 988 & 5961 & 1058 \\
\hline & Total & 2627 & 12521 & 145762 & 12404 \\
\hline
\end{tabular}

Table 8: Details of Deras that changed their migration routes from 2008-2010

\begin{tabular}{|c|c|c|c|c|c|c|}
\hline \multirow[b]{2}{*}{ JCPs } & \multicolumn{2}{|c|}{2008} & \multicolumn{2}{|c|}{2009} & \multicolumn{2}{|c|}{2010} \\
\hline & Migrated & Reverse & Migrated & Reverse & Migrated & Reverse \\
\hline Behramgala & 949 & 421 & 367 & 366 & 803 & 280 \\
\hline Kulali & 448 & 438 & 231 & 231 & 152 & 13 \\
\hline Marhot & 1161 & 1161 & 1130 & 412 & 1520 & 691 \\
\hline Mandi & 657 & 653 & 730 & 685 & 964 & 372 \\
\hline Thanamandi & 943 & 876 & 1017 & 898 & 853 & 881 \\
\hline Darhal & 667 & 244 & 456 & 205 & 315 & 213 \\
\hline Kandi & 526 & 557 & 447 & 192 & 209 & 178 \\
\hline
\end{tabular}

Source: Joint Check Posts (JCPs) Records 2012

An analysis of reverse migration data of the nomads clearly establishes the fact that most of the livestock carried by Deras was sold off by them. This is an obvious outcome based on the fact that they earn some money by their sale especially during the festivities after Ramzan. This also impacts their migration routes. During the seasonal migration, the route of induction and de-induction differs every year. Not necessarily the Deras will return by the same route as it had taken to induct. At times if their livestock is disposed off, the members may move back by road. The pattern of onward and return migration is also unlikely to confirm to a set pattern of sticking to one route/mode of returning during the winters. The movement pattern of various carvans or Deras shows that there is marginal variation in the route of induction. The deras may also return by the surface transport via Jammu even if the livestock is not disposed off.

The improvement of the Mughal Road has been a major factor in the increase in deras movement via Behramgala. Deras have been able to move along the valley and reach the road approximately five $\mathrm{km}$ short of Pir Gali. The worst stretch of movement to Pir Gali is normally the climb to the pass and thus the Deras are now able to move along the road alignment. The wider pass is lowest on the Pir Panjal ranges and thereafter the movement is a reasonably good one along the road for some distance and then via the valley selected by the dera. This is the main reason for the increase in Dera movement via Behramgala.

\section{Conclusions}

Clearly, the migratory practices of nomadic Gujjar Bakkarwal population of Jammu and Kashmir have been impacted by the armed conflict. Not only more and more Gujjars and Bakkarwals are settling in the plains for fear of terrorists, but the fodder shortage due to closure of pastures and forest areas is also posing problems for them.

Besides, the Gujjar Bakkarwals have no adequate political voices especially the Bakkarwals have not a single member in the Gujjar Bakkarwal Advisory Board. The Gujjar Bakkarwal Advisory Board possesses great 
authority in determining who from the Below Poverty Line section, will get access to various schemes. There should be at least one Bakkarwal member on the board. As both the Gujjars and Bakarwals gain greater political power they will be able to demand and control developmental funds for their own areas. Government should formulate a plan to protect their nomadic identity by providing them education and health facilities during their migration at upper reaches.

Therefore, for the betterment of the Gujjar Bakkarwal community, corrective measures must be taken by the government. Adequate security needs to be given to them while on seasonal migration, more channels of communication should be available to them so that in remote isolated place so that they can get in touch with administration and security forces in times of need. The nomadic Deras move freely across higher ranges of Pir Panjal ranges. Due to lack of communication with the security forces or the district administration, they face terror or climatic urgencies. They are not able to contact anybody and thus suffer a lot. There are no adequate communication networks among the nomadic population and the security forces or administration which can not only provide them with the latest information about the various terrorists operating in the higher ranges and their outfits, activity patterns etc but also will also help them in case of bad weather conditions or sudden rainfall etc. and thus launch Rescue and Relief operations. There are many instances wherein the army came to the rescue of hundreds and thousands of Bakkarwals in $\mathrm{J} \& \mathrm{~K}$ in higher reaches when sudden cold and snowfall took a toll of them and their cattle. Thus stronger means of communication are also required.

\section{References}

[1]. A.N. Bhardwaj (1994), History and Culture of Himalayan Gujjars, Jay Kay Book House, Jammu 1994

[2]. Behera, D.K. (1999): Contemporary Society: Tribal Studies, Social concept, New Delhi: Concept Publications Vol.4.

[3]. Chaturbhuj, Sahu. (2006): Aspects of Tribal Studies. New Delhi: Sarup \& Sons Publications.

[4]. Joshi, V. (1998): Tribals Situation in India: Issues in Development, Jaipur: Rawat Publications.

[5]. Kango, GH. \& Dhar, B. (1981): Nomadic Routes in Jammu and Kashmir, Studies in Transhumant and Pastoralism in the Northwest Himalayas, Srinagar: Directorate of Soil Conservation.

[6]. Khatana, R.P (1976): Marriage and Kinship among the Gujar Bakarwals of Jammu and Kashmir, Delhi. Ramesh Chandra Publications.

[7]. Mittal, A.C \& Sharma, J.B.M. (1988): Tribal movement, Politics, and Religion in India, Tribal movement in India, New Delhi: Radha Publications.

[8]. Sharma, Dash. P (2006): Anthropology of Primitive Tribes in India. Serials Publications 